Egyptian Journal of Aquatic Biology \& Fisheries

Zoology Department, Faculty of Science,

Ain Shams University, Cairo, Egypt.

ISSN $1110-6131$

Vol. 25(1): 633 - 642 (2021)

www.ejabf.journals.ekb.eg

\title{
Benthic Diatoms Utilization as Food for the Sand Sea Cucumber (Holothuria scabra)
}

\section{Anita Padang ${ }^{1}$, Niete Vuca Huliselan ${ }^{2}$, Rochman Subiyanto ${ }^{3}$ and Tekat Dwi Cahyono ${ }^{4}$ *}

1. STIKES Pasapua Ambon. Jl. Raya Suli, Waitatiri, Maluku Tengah, 97582, Indonesia.

2. University of Pattimura. Jl. Ir. M. Putuhena, Ambon, 97233, Indonesia.

3. Ambon Marine Culture Development Centre. J1. Laksdya Leo Wattimena, Waiheru, 97233, Ambon, Indonesia

4. University of Darussalam Ambon, Jl. Waehakila Puncak, Batu Merah, Ambon, 97128, Indonesia

*Corresponding Author: tekatdwicahyono@gmail.com

\section{ARTICLE INFO}

Article History:

Received: Oct. 24, 2020

Accepted: Dec. 28, 2020

Online: Feb. 14, 2021

Keywords:

Benthic diatoms, sand sea cucumber, Holothuria scabra, pen cultivation

\begin{abstract}
A variety of factors are apt to determine marine productivity; the most crucial of which is food supply in the marine environment. Diatoms, which belong to phytoplankton flora, may represent a food supply for sand sea cucumbers (Holothuria scabra) through deposit-feeding. Sand sea cucumber is one of the classes in the Echinodermata phylum, known for its soft-textured, fleshy, flat cylindrical body. Being continuously utilized, sand sea cucumbers possess a high economic value. However, over-usage may cause a decrease in its population. To overcome this problem, pen culture cultivation has proved its efficacy to guarantee a dominant sea cucumber flow of stocks. Sand sea cucumbers feed on naturally available elements in the cultivation process. Thus, this research was designed to investigate the utilization of benthic diatoms as food for sand sea cucumbers cultivated through pen culture. Observation of 70 sand sea cucumbers cultivated in 3 $\mathrm{m} \times 3 \mathrm{~m}$ size of pen culture was assessed. Seagrass leaves (Enhalus acroides) were planted in pen culture, as the habitat of benthic diatoms, whereas chicken feces represented the catalyst. Upon examinations, benthic diatoms were detected in almost $83 \%$ of sand sea cucumbers. Therefore, it is recommended to use benthic diatoms as a food supply for sand sea cucumber in cultivation purposes.
\end{abstract}

\section{INTRODUCTION}

Marine productivity depend on physical, chemical and aquatic biology parameters. Aquatic biota, particularly the diatoms, are food and energy sources for other organisms in food chain (King, 2013). There are two types of aquatic organisms; the pelagic which live in water column, and benthos which stick to the bottom of water (Naess, 2010). Due to the tiny size, filtered benthos organisms with a $0.5 \mathrm{~mm}$ sized benthic sieve are called macrobenthos (Mosbahi et al., 2016). 
Macrobenthos is one of the most important group in aquatic ecosystem due to their radical role in the food chain. According to how they eat, macrozoobenthos are divided into two groups; filter and deposit-feeder. The filter-feeder macrozoobenthos get their food by filtering the water, while the deposit-feeder attain food from the base substrate (Mitra \& Zaman, 2016; A Wahab et al., 2018).

Bacillariophyceae or Diatoms, classified as belonging to phytoplankton, are food supply for macrobenthos. Morphologically, Diatoms have two orders: Centrales with radial symmetry valves that live in the water column dominantly, and Pennales with bilateral symmetry valves that live in the substrate dominantly (Lalli \& Parsons, 1997; Sommer, 2012; F Ayoub et al., 2019). Members of Pennales are the primary food producers in the life of benthic organisms. According to Padang (2012), the benthic diatoms play an important role in water column ecosystem, serving as food depositfeeding benthic organism such as sea cucumber.

Sea cucumber (Holothuroidea) is systematically included in Phylum Echinodermata, which is one of the edible marine animals and fisheries commodities that own a high economic value because of their nutritional content. Padang et al. (2015) found that the protein content of sea cucumber was 3.23-6.98\% (wet) and 33.13-43.36\% (dry). Notably, among sea cucumber, the sand sea cucumber (Holothuria scabra)is highly priced (Teniwut, 2016).

Sand sea cucumber (Holothoria scabra) in the domestic market has a selling value of Rp. 900,000,-/ kg, this causes sand sea cucumbers to be continuously used. So far, the production of sea cucumbers is generally obtained from catching in the wild, where the resources are increasingly limited. Thus, in order to meet the market demand, cultivation should be considered.

This research is about to analyze the changes in the composition of benthic diatoms in the stomach of the sand sea cucumber (Holothuria scabra) fixedly-kept-in-cages or pen culture.

\section{MATERIALS AND METHODS}

This research was conducted for 5 months in the coastal area of Hunut Village, Ambon City. The fixedly-kept-in-cages are located at $03^{\circ} 38^{\prime} 01,4$ " of Latitude and $128^{\circ} 12^{\prime} 56,4^{\prime \prime}$ of East Longitude. Seventy sea cucumbers were kept in a 3 x 3 meters sized cage, 70 sea cucumbers are kept. They were collected from nature with reference to the method of Tomatala et al. (2018). In fixedly-kept-in-cages, Enhalus acroides leaves were inserted as a habitat for benthic diatoms, and a dose of chicken faeces was assisted to stimulate the growth of benthic diatoms.

Analysis of the stomach contents of sea cucumbers was carried out at the Biology laboratory of Universitas Darussalam Ambon, which was carried out by cutting the stomach from the anterior to the posterior to extract the stomach. Then, the contents of the stomach were removed and put into a container with the addition of $4 \%$ formalin, 
which is hardened with borax. The contents of the sea cucumber stomach, preserved in formalin, were taken with a $1 \mathrm{ml}$ pipette and placed on a hem cytometer to be observed using a 400-magnification Olympus microscope to identify the stomach contents of the sea cucumber (Tomas, 1997; Castellani \& Edwards, 2017).

Analysis of the stomach contents of sea cucumbers included:

a. The composition of benthic diatoms in the stomach of sea cucumbers and sediments based on a formula according to Ferianita (2007).

$$
\text { Composition }(\%)=\frac{\sum \text { individuals of a kind }}{\sum \text { individuals of a kind }}
$$

b. Selectivity Index

The use of benthic diatoms in sediment by sea cucumbers will be analyzed based on the Selectivity Index (Index of Choice) in Effendie (1997) as follows:

$$
E=\frac{r i-p i}{r i+p i}
$$

Where:

$E=$ Selectivity Index

$r i=$ Presentation of food (benthic diatoms) in the stomach of sea cucumbers

$p i=$ Presentation of food (benthic diatoms) in sediments

\section{RESULTS AND DISCUSSION}

\subsection{Food Composition in Sea Cucumber Stomach.}

Figure 1a shows the composition of food in the stomach of sand sea cucumbers collected in nature (Padang et al., 2014a). Furthermore, figure $1 \mathrm{~b}$ presents the composition of food in the stomach of cultivated sand sea cucumbers. Both figure 1a and $1 \mathrm{~b}$ show the equation, namely, the dominance of diatom phytoplankton.

Sea cucumbers, reared in fixed confinement, consisted of diatom and zooplankton class phytoplankton with a greater presentation of benthic diatoms (89\%) than zooplankton (11\%). Besides, phytoplankton of Class Cyanophycea $(0.209 \%)$ and seagrass leaves $(0.088 \%)$ were also found. The small presentation of Cyanophycea and Seagrass Enhalus acroides leaves is possible because diatom growth is faster with the addition of chicken manure. Previous researchers reported that the composition of food in the stomach of sea cucumbers in nature consisted of zooplankton and phytoplankton class Cyanophycea and Diatom or Bacillariophyceae (Padang et al., 2014a). Diatoms are classified as a class of phytoplankton that is often found in Indonesian waters (Komalasari et al., 2020). Hamid (2019) found types of food in the intestines of sea cucumbers including Diatoms, Foraminifera, Detritus, Nematodes, Radiolaria, Protozoa 
and Crustacean Larvae, and noted that the largest percent composition of the food group was diatoms, with estimation $>50 \%$. Padang and Subiyanto (2019) found that the composition of the feed on sea cucumbers, kept in floating net cages with three treatments, turned out to be dominated by the diatom class phytoplankton or Baccilariophycea. Diatoms are preferably herbivorous zooplankton because of the form of non-filamentous cells (Mulyawati et al., 2019).

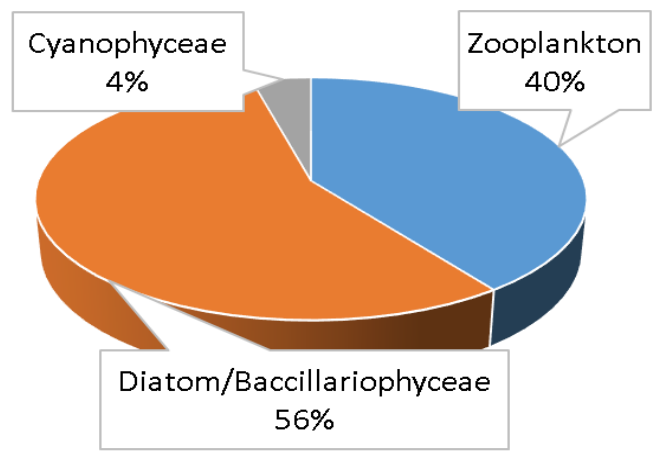

(a)

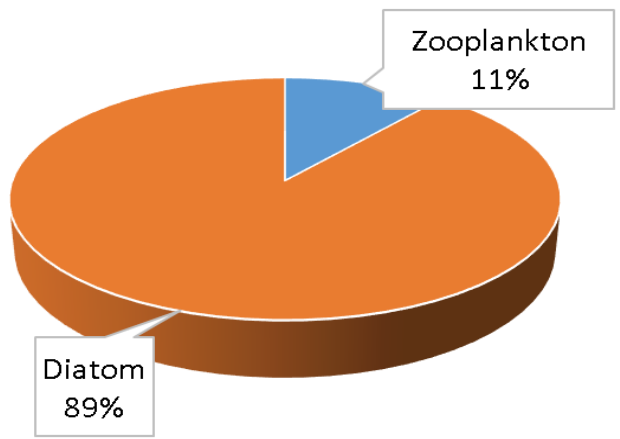

(b)

Fig. 1: (a). Food Composition of Sea Cucumbers in Nature; (b). Composition of Sea Cucumber Food in Pen culture

\subsection{Composition of benthic diatom genus in sea cucumber stomach}

The results showed that the number of benthic diatom genera, kept in culture, was 23 genera (Figure. 2b). The dominant genus is Navicula (10 species), and the next is also dominated by the genus Amphora (7 species) and Nitzschia with 7 species each. The previous findings were in agreement with that of Padang et al. (2014), where the number of benthic diatoms in the stomach of sea cucumbers that live in nature is dominated by the Order pennales, namely, Amphora (8 species), Navicula (14 species) and Nitzschia (10 species). The difference in the types of benthic diatoms, found in the hulls of sand sea cucumbers, is possible because the sand sea cucumbers, with their semimobile movements in nature, can freely forage without being limited within a culture container so that more types of benthic diatoms can be consumed. Addingly, sand sea cucumbers are non-selective organisms in consuming food. 


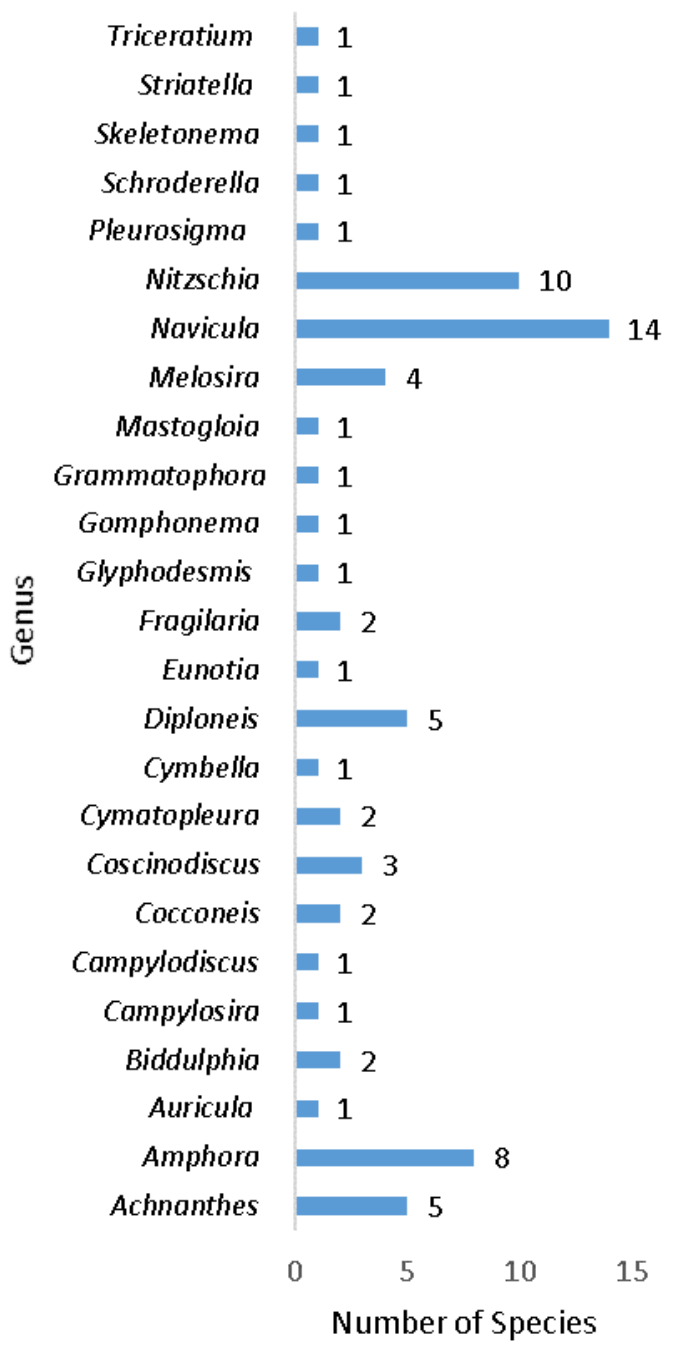

(a)

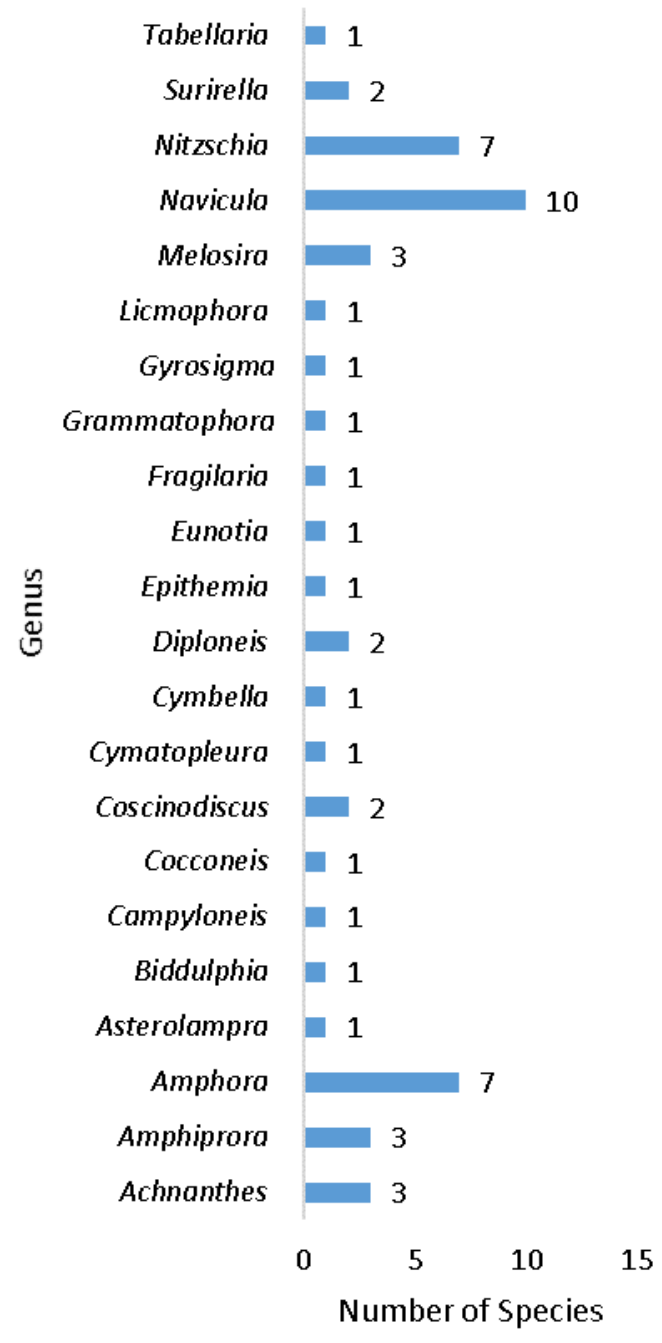

(b)

Fig. 2: (a). Composition of Natural Sea Cucumber Benthic Diatom; (b). Composition of Sea Cucumber Diatom Genus in Pen culture

\subsection{Composition of the Genus of Benthic Diatoms in Sediment in Nature and in Culture}

The composition of benthic diatoms in sediments in the container for fixed captivity/culture of 20 genera was dominated by the genus Amphora (4 species), Navicula (10 species) and Nitzschia (5 species). This is different from previous studies which explained that the composition of the genus of benthic diatoms in sediments, collected in nature, were 24 genera, dominated by the genus Amphora (7 species), Navicula (9 species) and Nitzschia (11 species) (Padang et al., 2014a). It appears that the genera of benthic diatoms in nature are more numerous than those in fixed confinement containers. This is due to the availability of benthic diatom food in nature which has a wider habitat than in rearing containers limited by fixed confinement. However, benthic diatoms still 
dominate the culture container, so that the sand sea cucumbers that are maintained have many opportunities to consume benthic diatoms. The details can be seen in Figure 3.

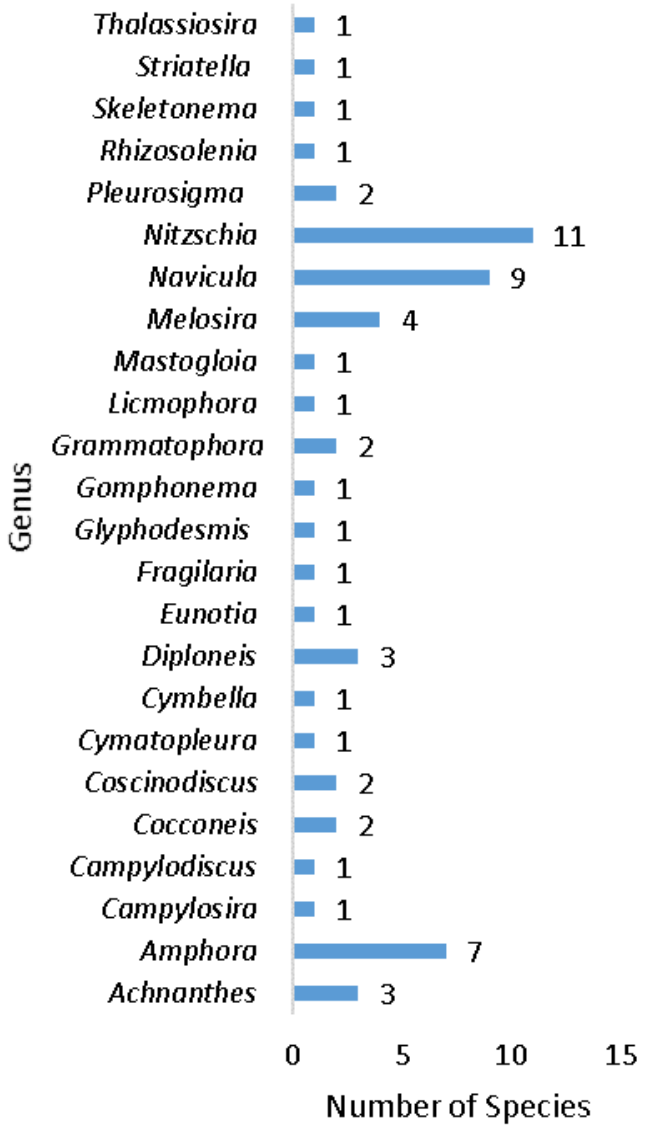

(a)

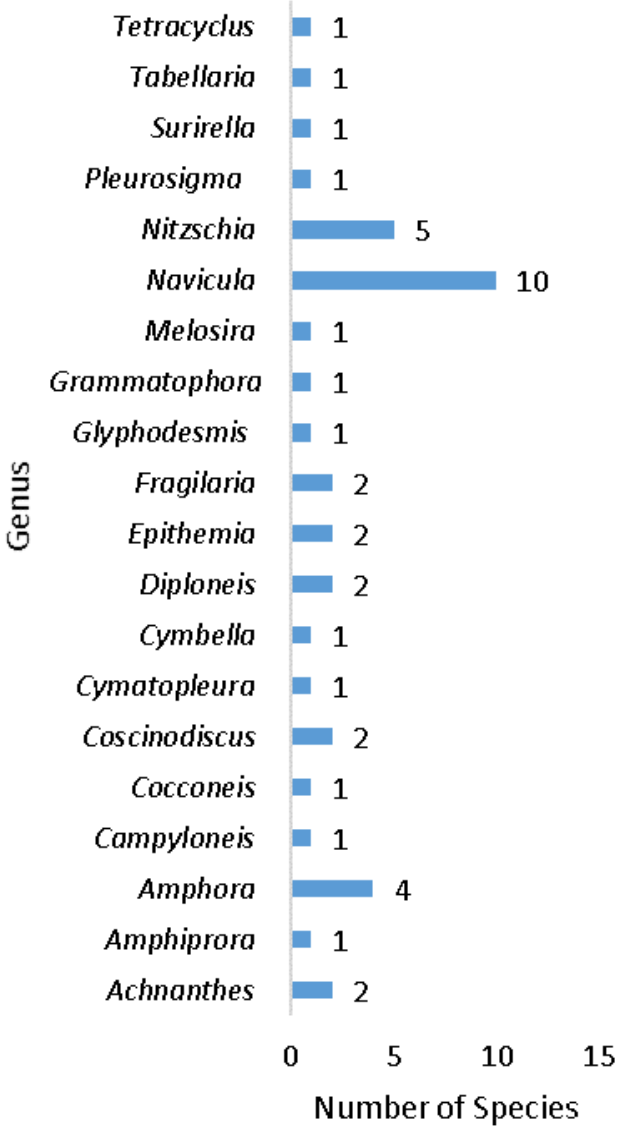

(b)

Fig. 3: (a) Composition of the Genus of Benthic Diatoms in Nature; (b). Composition of the Genera of Sedimentary Benthic Diatoms in Pen Culture

Benthic diatoms are the most common phytoplankton group compared to other groups, as found in Effendy and Patadjai (2018) in the maintenance of abalone (Haliotis asinina) which obtained the most benthic diatom type composition in the collector and abalone leg muscles by $98 \%$. Ariana et al. (2014) stated that the many classes of Bacillariophyceae (Diatom) in waters are cosmoplitant, caused by their ability to adapt to the environment, resistant to extreme conditions, and have high reproductive power. Furthermore, Mercier and Hamel (2009) indicated that, compared to other genera from other classes, phytoplankton from Bacillariophyceae (Diatom) has a very fast response to nutrient addition and is able to adapt to the environment. 


\subsection{Selectivity Index}

The selectivity index of sea cucumbers kept in fixed confinement is 0.03 , which indicates that the benthic diatoms are not favored by sand sea cucumbers. Effendie (1997) explained that if the value of $\mathrm{E}=1$ means that there is no selection of food, and if E $>1$ there is a choice of food, whereas, if $\mathrm{E}<1$ then the food is not popular. Furthermore, the selectivity index for sea cucumbers in nature found by Padang et al. (2014a) was 0.256 . This shows that although the selectivity value of sea cucumber maintained in culture $(E<1)$, it is greater than in nature. Sand sea cucumber is a non-selective organism , with respect to choosing food, so that it still uses benthic diatoms as food because the availability of benthic diatoms is large enough in a culture container or in nature. Meanwhile, Hamid (2019) found that diatoms are important for sea cucumbers as food supply, and can be categorized as the main food of $H$. scabra sand sea cucumber.

Furthermore, Xia et al. (2017) stated that the main food is food that is eaten in large quantities, and added that complementary foods are foods that are found in the digestive tract less. This study found a large benthic diatom composition in the hull of the sand sea cucumber (H. sacbra) so that the benthic diatoms are the main food for H.scabra. According to Hamid (2019), the factors that determine the food-organism relation are: food size, food availability, food color, and taste. Moreover, the amount of food needed by a type of aquatic organism depends on the type of food, food habits, water temperature, and the general condition of the organism.

Hendri et al. (2009) found that sea cucumbers, in the larval stage, experienced good growth and survival by giving benthic diatoms compared to green algae. This proves that benthic diatoms are a type of phytoplankton favored by sand sea cucumbers.

Cultivation of sea cucumber in nature can be carried out by maintaining it in a cage (pen culture), where sand sea cucumbers can take the food from their natural habitat directly; benthic diatoms. Padang et al. (2014a) estimated the use of benthic diatoms as food for sea cucumbers by 56\% and Padang et al. (2014b) recorded that the growth rate of sand sea cucumbers in controlled containers was the highest by consuming benthic diatoms of the type Navicula sp.).

Setiawan (2015) stated that phytoplankton plays a role in both the flow of energy to form feed nets and in nutrient cycling and oxygen production as well. The net productivity resulting from photosynthetic phytoplankton will be transferred to various components of the ecosystem. The energy potential that is manifested in phytoplankton biomass is transferred to various animals through the food chain. Thus, the life of all animals depends on the energy obtained from phytoplankton, either directly or indirectly (Siokou-Frangou et al., 2010). The level of water fertility can be indicated by the abundance of phytoplankton because they occupy the lowest trophic level which directly utilizes nutrients in the waters (Radiarta et al., 2015). 


\section{CONCLUSION}

It is concluded that benthic diatoms utilized by sand sea cucumbers was estimated by $89 \%$. Genus Navicula is a species that dominates the stomach contents of sea cucumbers. Moreover, the selectivity index shows that benthic diatoms are not favored by sea cucumbers, but they are non-selective biota in choosing food so that benthic diatoms are still used by sea cucumbers. Further research is needed on the maintenance of sea cucumber larvae using benthic diatoms as natural food.

\section{REFERENCES}

A Wahab, H. M.; Iskaros, I. A.; Fishar, M. R. and Mohamed, N. E. (2018). Ecological studies on macrobenthic invertebrates in four northern Khors of Lake Nasser (Egypt); Community Structure, Relative Abundance and Diversity. Egyptian Journal of Aquatic Biology and Fisheries, 22(3): 111-124.

Ariana, D.; Samiaji, J. and Nasution, S. (2014). Komposisi jenis dan kelimpahan fitoplankton perairan laut riau. Riau University.

Castellani, C. and Edwards, M. (2017). Marine plankton: A practical guide to ecology, methodology, and taxonomy: Oxford University Press.

Effendie, M. I. (1997). Biologi perikanan. Yayasan Pustaka Nusatama. Yogyakarta, 163.

Effendy, I. J. and Patadjai, A. B. (2018). Komposisi Jenis dan Kepadatan Bentik Diatom pada Kolektor dan Kaki/otot Abalon (Haliotis asinina) yang Dipelihara di Kawasan Sistem IMTA (Integrated Multi Trophic Aquaculture) Out Door. Jurnal Media Akuatika, 3(1): 544-556.

F Ayoub, H.; F Abdelghany, M. and B El-Sayed, A. E.-K. (2019). Effects of Diatoms Amphora coffeaeformis on growth parameters, non specific immunity and protection of the Nile tilapia (Oreochromis niloticus) to Aeromonas hydrophila infection. Egyptian Journal of Aquatic Biology and Fisheries, 23(1): 413-426.

Ferianita, F. M. (2007). Metode Sampling Bioekologi. Jakarta: Bumi Aksara.

Hamid, A. (2019). Studi Kebiasaan Makan Teripang Pasir (Holothuria scabra) di Perairan Desa Alosi Kecamatan Kolono Kabupaten Konawe Selatan. Jurnal Manajemen Sumber Daya Perairan, 4(1): 15-22.

Hendri, M.; Sunaryo, A. I. and Pahlevi, R. Y. (2009). Tingkat kelulusan hidup larva teripang pasir (Holothuria Scabra, Jaeger) dengan perlakuan pemberian pakan 
alami berbeda di balai besar pengembangan budidaya laut (BBPBL) Lampung. Jurnal Penelitian Sains, 12(1): 1-5.

King, M. (2013). Fisheries biology, assessment and management: John Wiley \& Sons.

Komalasari, E.; Khairuddin, K. and Japa, L. (2020). The Diatom Community in Maluk Coastal Water in West Sumbawa. Paper presented at the 1st Annual Conference on Education and Social Sciences (ACCESS 2019).

Lalli, C. and Parsons, T. R. (1997). Biological oceanography: an introduction: Elsevier.

Mercier, A. and Hamel, J.-F. (2009). Advances in marine biology: endogenous and exogenous control of gametogenesis and spawning in echinoderms: Academic Press.

Mitra, A. and Zaman, S. (2016). Basics of marine and estuarine ecology: Springer.

Mosbahi, N.; Pezy, J.-P.; Dauvin, J.-C. and Neifar, L. (2016). Spatial and temporal structures of the macrozoobenthos from the intertidal zone of the Kneiss Islands (Central Mediterranean Sea). Open Journal of Marine Science, 6(02): 223-237.

Mulyawati, D.; Ario, R. and Riniatsih, I. (2019). Pengaruh Perbedaan Kedalaman Terhadap Fitoplankton dan Zooplankton Di Perairan Pulau Panjang, Jepara. Journal of Marine Research, 8(2): 181-188.

Naess, A. (2010). The Basics of Deep Ecology Movement [J]. Journal of Poyang Lake, 6.

Padang, A. (2012). Peranan Diatom Bagi Produktivitas Primer di Lingkungan Bentik. BIMAFIKA: Jurnal MIPA, Kependidikan dan Terapan, 4(1): 420-424.

Padang, A.; Lukman, E. and Sangadji, M. (2014a). Komposisi makanan dalam lambung teripang. Agrikan: Jurnal Agribisnis Perikanan, 7(2): 26-30.

Padang, A.; Lukman, E. and Sangadji, M. (2014b). Pemanfaatan diatom bentik sebagai makanan teripang dalam rangka pengembangan usaha budidaya teripang. Paper presented at the Prosiding Seminar Nasional Penguatan Pembangunan Berbasis Riset Perguruan Tinggi (SPP-RPT) I.

Padang, A. and Subiyanto, R. (2019). Food Composition in the Hull of Sand Cucumber (Holothuriascabra) Kept at Floating Net Cages. Paper presented at the Journal of Physics: Conference Series. 
Radiarta, I. N.; Erlania, E. and Sugama, K. S. K. (2015). Analisi Spasial Dan Temporal Komunitas Fitoplankton Sekitar Budidaya Laut Terintegrasi di Teluk Ekas, Nusa Tenggara Barat Jurnal Riset Akuakultur, 10(2): 283-291.

Setiawan, N. E. (2015). Produktivitas Primer dan Kelimpahan Fitoplankton Pada Area Yang Berbeda Di Sungai Betahwalang, Kabupaten Demak. Journal of Management of Aquatic Resources, 4(3): 195-203.

Siokou-Frangou, I.; Christaki, U.; Mazzocchi, M. G.; Montresor, M.; Ribera d'Alcalà, M.; Vaqué, D. and Zingone, A. (2010). Plankton in the open Mediterranean Sea: a review.

Sommer, U. (2012). Plankton ecology: succession in plankton communities: Springer Science \& Business Media.

Teniwut, W. A. (2016). For sustainable revenue of fisheries sector in small islands: evidence of Maluku, Indonesia. Aquaculture, Aquarium, Conservation \& Legislation, 9(3): 722-732.

Tomas, C. R. (1997). Identifying marine phytoplankton: Elsevier.

Tomatala, P.; Letsoin, P. P. and Kadmaer, E. M. Y. (2018). The Effectiveness of pen-culture construction for cultivation of sea cucumber. Jurnal Akuakultur Indonesia, 17(1): 26-33.

Xia, B.; Ren, Y.; Wang, J.; Sun, Y. and Zhang, Z. (2017). Effects of feeding frequency and density on growth, energy budget and physiological performance of sea cucumber Apostichopus japonicus (Selenka). Aquaculture, 466: 26-32. 